\title{
Yoga for Menopausal Symptoms: A Review
}

\author{
Denise Permatasari \\ Universitas Muhammadiyah Malang \\ denise_permatasari@yahoo.com
}

\begin{abstract}
The purpose of this study was to review literature about the effectiveness of yoga as a treatment for menopausal symptoms. This study use 10 literature where published on International Journal from 2007-2016. Most of literature used perimenopausal and postmenopausal woman as treatment subjects. This data collect show the results compare between control group and yoga group. They assessed the effect of yoga as treatment for menopausal symptoms (psychological, vasomotor and somatic). This review found evidence to suggest that yoga effective as additional treatment for menopausal symptoms.
\end{abstract}

Keyword: yoga, menopausal symptoms, review

\section{BACKGROUND}

Menopause is a term to describe when the menstrual period ended permanently. Menopause typically occurs between 40 s and 50 s of age, when menstruation permanently ends (Santrock, 2012). Normal menopause is considered one of the most physiologically important in women's life because of cessation of ovarium regular function and the end of reproductive capability (Nichols et al, 2012).

The decrease of estrogen hormone production in menopause has a quite detrimental effect to women's health, including the increase of the risk contracting several diseases, such as osteoporosis, cardiovascularrelated disease and Alzheimer (Torre, 2015). Hot flashes is a most common symptom which happens to a woman in the early stage of menopause, which is increase in body temperature in 2-30 minutes in upper chest, there are several symptoms such as sudden perspiration during night time, palpitation or sudden increase of heartbeat frequency (Cooper et al, 2008), fear and anxiety of which contributed to the decrease of sexual drive, mood swing, unstable emotion (discomfort, anxiety, depression) and difficulty in memorizing and remembering (McVeigh, 2005) to a degree that some women will experience difficulty to sleep. This symptoms is categorized as vasomotor symptoms (VMS) and these symptoms will occur to $75 \%$ of the women who were experiencing menopause

Some women who were in menopause felt some discomfort due to the following symptoms and tried to treat the symptoms to a certain degree so that such treatment will lessens or even cure the symptoms, one of the treatment is Yoga (Cramer, Lauche, Langhorst, \& Dobos, 2012). Yoga practice commonly done is posture (asana), breath control (pranayama) and meditation (dhyana). Women who practice Yoga regularly is shown to have some degree of improvement of their menopause symptoms, which is hot flashes and reduced perspiration during night time

(Innes, Bourguignon, \& Taylor, 2005). Meditation is part of Yoga and meditation could increase melatonin and plasma melatonin level effectively, which could increase the sleep quality for women with menopause (Cohen \& Wameke, 2004). Yoga is effective in improving sleep cycle, reducing insomnia symptoms and other sleep difficulties for women with menopause (Khalsa, 2004).

\section{PROCEDURAL REVIEW}

Information regarding the research is done by searching literature in the form of article and scientific journal, which are:
1. www.eric.ed.gov
2. www.scholar.google.com
3. www.menopause.org
4. www.libgen.org

Keyword used in searching of literature in the form of scientific journal are menopause, yoga and menopausal symptoms. From these keyword then the information related to the research is retrieved in the form of 10 scientific journal.

\section{RESULTS OF REVIEW AND STUDY}

After reviewing these 10 journal about menopausal symptoms and Yoga for women with menopause, presented below in the form of table are summary of the study. These summary is presented with the intention of providing comprehensive description about the content of the reviewed journal, and the next step is to discuss the conclusion of the research results. 
Summary of Research Result Characteristic Table

\begin{tabular}{|c|c|c|c|c|c|c|c|c|}
\hline $\begin{array}{l}\text { Author } \\
\text {, year }\end{array}$ & $\begin{array}{l}\text { Number } \\
\text { of subject }\end{array}$ & $\begin{array}{l}\text { Subject } \\
\text { description }\end{array}$ & $\begin{array}{l}\text { Treatment } \\
\text { group }\end{array}$ & $\begin{array}{l}\text { Control } \\
\text { group }\end{array}$ & Duration & $\begin{array}{l}\text { Treatment } \\
\text { purpose }\end{array}$ & Result & Author's conclusion \\
\hline $\begin{array}{l}\text { Afonso } \\
\text { et al } \\
(2012)\end{array}$ & $\begin{array}{l}=44 \rightarrow \\
3 \\
\text { oga (15), } \\
\text { control } \\
(15), \\
\text { passive } \\
\text { stretching } \\
\text { (14). }\end{array}$ & $\begin{array}{l}50-65 \\
\text { years, } \\
\text { Postmenopau } \\
\text { se, Not in a } \\
\text { hormone } \\
\text { therapy, }\end{array}$ & $\begin{array}{l}\text { Yoga } \rightarrow \\
\text { Treatment } \\
\text { in the form } \\
\text { of Yoga in } \\
\text { Yogasana } \\
\text { and } \\
\text { Tibetan } \\
\text { (Yoga HT } \\
\text { is for } \\
\text { menopause } \\
\text { ) }\end{array}$ & $\begin{array}{l}\text { Control } \rightarrow \\
\text { No } \\
\text { treatment } \\
\text { assive } \\
\text { stretching } \\
\rightarrow \\
\text { Treatment } \\
\text { in the form } \\
\text { of stretching } \\
\text { form, done } \\
\text { by physical } \\
\text { therapist }\end{array}$ & 4 months & $\begin{array}{l}\text { Reducing } \\
\text { insomnia, } \\
\text { Improving } \\
\text { climacteric } \\
\text { symptoms } \\
\text { (anxiety, } \\
\text { stress, } \\
\text { depression) }\end{array}$ & $\begin{array}{l}\text { Yoga group scores } \\
\text { better in } \\
\text { posttreatment. } \\
\text { Climacteric } \\
\text { symptoms, insomnia, } \\
\text { quality of life and } \\
\text { stress resilience are } \\
\text { improving. The } \\
\text { decrease of insomnia } \\
\text { severity in Yoga } \\
\text { group is noticeably } \\
\text { higher compared with } \\
\text { control group and } \\
\text { passive stretching } \\
\text { group. }\end{array}$ & $\begin{array}{l}\text { Yoga with specific } \\
\text { and sequenced } \\
\text { treatment are very } \\
\text { effective in reducing } \\
\text { insomnia caused by } \\
\text { menopausal } \\
\text { symptoms which } \\
\text { also increases the } \\
\text { quality of life. }\end{array}$ \\
\hline $\begin{array}{l}\text { ee, } \\
\text { Kim, \& } \\
\text { Kim } \\
(2012)\end{array}$ & $\begin{array}{l}=16 \rightarrow \\
2 \quad \text { Yoga } \\
(8), \\
\text { control } \\
(8) .\end{array}$ & $\begin{array}{l}54,50 \pm 2,75 \\
\text { years, } \\
\text { postmenopau } \\
\text { se, body fat } \\
\text { is more than } \\
36 \%\end{array}$ & $\begin{array}{l}\text { Yoga } \rightarrow \\
\text { Treatment } \\
\text { in the form } \\
\text { of } \\
\text { integrated } \\
\text { coordinatio } \\
\mathrm{n} \text { technique } \\
\text { of } \\
\text { breathing } \\
\text { and } \\
\text { movement }\end{array}$ & $\begin{array}{l}\text { Control } \\
\rightarrow \quad \text { No } \\
\text { treatment }\end{array}$ & 16 weeks & $\begin{array}{l}\text { Increasing } \\
\text { lipid } \\
\text { concentratio } \\
\mathrm{n}, \text { adipose } \\
\text { tissue and } \\
\text { syndrome } \\
\text { metabolic } \\
\text { factor in } \\
\text { obesity }\end{array}$ & $\begin{array}{l}\text { Weight, body fat } \\
\text { percentage, body } \\
\text { mass index with no } \\
\text { regard to muscle/fat } \\
\text { ratio, body mass } \\
\text { index, waist size and } \\
\text { visceral fat region } \\
\text { shows a significant } \\
\text { decrease. }\end{array}$ & $\begin{array}{l}\text { Yoga is effective in } \\
\text { reducing the risk of } \\
\text { contracting } \\
\text { cardiovascular } \\
\text { disease which caused } \\
\text { by obesity in Korean } \\
\text { woman in } \\
\text { menopause. }\end{array}$ \\
\hline $\begin{array}{l}\text { Newto } \\
\mathrm{n} \text { et al } \\
(2013)\end{array}$ & $\begin{array}{l}=355 \rightarrow \\
2 \text { group } \\
\text { oga } \\
(107), \\
\text { Control } \\
(142)\end{array}$ & $\begin{array}{l}45 \quad-\quad 65 \\
\text { years, } \\
\text { postmenopau } \\
\text { se }\end{array}$ & $\begin{array}{l}\text { Yoga } \rightarrow \\
\text { Breathing } \\
\text { technique, } \\
\text { pose } \\
\text { (asanas), } \\
\text { dan } \\
\text { relaxation }\end{array}$ & $\begin{array}{l}\text { Control } \rightarrow \\
\text { No } \\
\text { treatment, } \\
\text { just regular } \\
\text { activity }\end{array}$ & 12 weeks & $\begin{array}{l}\text { Reducing } \\
\text { the } \\
\text { frequency } \\
\text { of } \\
\text { vasomotor } \\
\text { symptoms }\end{array}$ & $\begin{array}{l}\text { Control Group } \rightarrow \\
\text { VMS 8,0 per hari } \\
(95 \% \text { CI, } 7,3 \text { ke } 8,7) \\
\text { Yoga Group } \rightarrow \\
\text { VMS 7,4 per hari } \\
(95 \% \text { CI, 6,6 ke } 8,1) \\
\text { Gejala insomnia } 1,3 \\
(95 \% \text { CI, -2,5 ke - } \\
0,1): P=0,007\end{array}$ & $\begin{array}{l}\text { Practicing yoga for } \\
12 \text { weeks and } \\
\text { personal training in } \\
\text { home, when } \\
\text { compared by regular } \\
\text { activity shows no } \\
\text { impact on reducing } \\
\text { any vasomotor } \\
\text { symptoms, the only } \\
\text { improvement } \\
\text { observed is in the } \\
\text { decrease } \\
\text { prevalence of the } \\
\text { insomnia }\end{array}$ \\
\hline $\begin{array}{l}\text { Afonso } \\
\text { Kozasa } \\
\text { Rodrig } \\
\text { ues, } \\
\text { Leite, } \\
\text { Tufik, } \\
\& \\
\text { Hachul } \\
\text { (2016) }\end{array}$ & 2 & $\begin{array}{l}56 \text { and } 58 \\
\text { years, } \\
\text { Postmenopau } \\
\text { se, follicle } \\
\text { hormone } \\
\text { level }\end{array}$ & $\begin{array}{l}\text { Yoga } \rightarrow \\
\text { Breathing } \\
\text { technique, } \\
\text { relaxation } \\
\text { dan yoga } \\
\text { posture }\end{array}$ & & 4 month & $\begin{array}{l}\text { To observe } \\
\text { quality of } \\
\text { life and } \\
\text { estradiol } \\
\text { (part of } \\
\text { estrogen) }\end{array}$ & $\begin{array}{l}\mathrm{N}_{1} \mathrm{QOL}_{\text {pre }} \rightarrow 136 \\
\mathrm{QOL}_{\text {post }} \rightarrow 110 \\
\mathrm{E}_{2 \text { pre }} \rightarrow<10 \\
\mathrm{E}_{2 \text { post }} \rightarrow 94 \\
\mathrm{~N}_{2} \mathrm{QOL}_{\text {pre }} \rightarrow 106 \\
\mathrm{QOL}_{\text {post }} \rightarrow 80 \\
\mathrm{E}_{2 \text { pre }} \rightarrow 17 \\
\mathrm{E}_{2 \text { post }} \rightarrow 137\end{array}$ & $\begin{array}{l}\text { Yoga affects the } \\
\text { neuroendocrine } \\
\text { system in way that } \\
\text { increase the amount } \\
\text { of estrogen, which } \\
\text { improves quality of } \\
\text { life }\end{array}$ \\
\hline $\begin{array}{l}\text { Chatth } \\
\text { a, } \\
\text { Raghur } \\
\text { am, } \\
\text { Venkat } \\
\text { ram, \& } \\
\text { Hongas } \\
\text { andra } \\
\text { (2008) }\end{array}$ & $\begin{array}{l}=120 \rightarrow \\
2 \text { Yoga } \\
(59), \\
\text { control } \\
(61)\end{array}$ & $\begin{array}{l}45 \quad-\quad 55 \\
\text { years, } \\
\text { Perimenopau } \\
\text { se (women in } \\
\text { menopause } \\
\text { stage), FSH } \\
\text { level } \\
\pm 15 \mathrm{mlU} / \mathrm{mL}\end{array}$ & $\begin{array}{l}\text { Yoga } \rightarrow \\
\text { IAYT } \\
\text { technique } \\
\text { (breathing } \\
\text { and } \\
\text { meditation } \\
\text { technique) }\end{array}$ & $\begin{array}{l}\text { Control } \rightarrow \\
\text { Light } \\
\text { physical } \\
\text { exercise }\end{array}$ & 8 weeks & $\begin{array}{l}\text { To observe } \\
\text { the impact } \\
\text { of yoga to } \\
\text { vasomotor } \\
\text { stress } \\
\text { symptom } \\
\text { and } \\
\text { personality }\end{array}$ & $\begin{array}{l}\text { Perceived Stress } \\
\text { Scale scores }(\mathrm{P}< \\
0.001) \text { in the yoga } \\
\text { group compared with } \\
\text { controls. Higher } \\
\text { effect size in the yoga } \\
\text { group (1.10) than the } \\
\text { control (0.27). On the } \\
\text { Eysenck's Personality } \\
\text { Inventory, the } \\
\text { decrease in } \\
\text { neuroticism was } \\
\text { (P<0.05) in the yoga } \\
\text { group (effect size = } \\
0.43) \text { than the control } \\
\text { group (effect size = } \\
0.21) \text { with no change } \\
\text { in extroversion in } \\
\text { either the yoga or } \\
\text { control group }\end{array}$ & $\begin{array}{lr}\text { Yoga is } & \text { reducing } \\
\text { vasomotor } & \\
\text { symptoms, stress and } \\
\text { neuroticism } & \text { in } \\
\text { perimenopause } & \\
\text { women } & \text { when } \\
\text { compared } & \text { with } \\
\text { regular } & \text { physical } \\
\text { exercise } & \end{array}$ \\
\hline
\end{tabular}




\begin{tabular}{|c|c|c|c|c|c|c|c|c|}
\hline $\begin{array}{l}\text { Cohen, } \\
\text { Kanaya } \\
\text { ' Macer, } \\
\text { Shen, } \\
\text { Chang, } \\
\& \\
\text { Grady } \\
(2007)\end{array}$ & $=14$ & $\begin{array}{l}\text { 40-65 years, } \\
\text { Postmenopau } \\
\text { se }\end{array}$ & $\begin{array}{l}\text { Yoga } \rightarrow \\
\text { Restorative }\end{array}$ & $\begin{array}{l}\text { Control } \rightarrow \\
\text { No } \\
\text { treatment }\end{array}$ & 8 weeks & $\begin{array}{l}\text { To find out } \\
\text { about } \\
\text { probability } \\
\text { and } \\
\text { intervention } \\
\text { acquirement } \\
\text { of } \\
\text { restorative } \\
\text { yoga in } \\
\text { relation to } \\
\text { hot flushes } \\
\text { experienced } \\
\text { by women } \\
\text { in } \\
\text { postmenopa } \\
\text { use }\end{array}$ & $\begin{array}{l}\text { Most of the subject is } \\
\text { satisfied with } \\
\text { practicing Yoga. } 75 \% \\
\text { are continuing the } \\
\text { exercise after } 3 \\
\text { months. The average } \\
\text { decrease of hot } \\
\text { flushes are } 30.8 \% \\
(95 \% \text { CI } 15,6-45,9 \%) \\
\text { and average hot flush } \\
\text { score is decreasing by } \\
34.2 \% \text { ( } 95 \% \text { CI } 16,0- \\
52.5 \% \text { from the } \\
\text { beginning until week } \\
8 \text {, no adverse impact } \\
\text { are found }\end{array}$ & $\begin{array}{l}\text { Yoga is a perfectly } \\
\text { acceptable } \\
\text { intervention by the } \\
\text { population }\end{array}$ \\
\hline $\begin{array}{l}\text { Joshi, } \\
\text { Khand } \\
\text { we, } \\
\text { Bapat, } \\
\& \\
\text { Deshm } \\
\text { ukh } \\
(2011)\end{array}$ & $\begin{array}{l}180 \\
2 \text { group } \\
\text { oga }(90), \\
\text { Control } \\
(90)\end{array}$ & $\begin{array}{l}40-55 \text { years, } \\
\text { postmenopau } \\
\text { se, No } \\
\text { hormone } \\
\text { therapy and } \\
\text { no Yoga } \\
\text { therapy }\end{array}$ & $\begin{array}{l}\text { Yoga } \rightarrow \\
\text { Breathing } \\
\text { technique, } \\
\text { posture and } \\
\text { meditation }\end{array}$ & $\begin{array}{l}\text { Control } \rightarrow \\
\text { No } \\
\text { treatment }\end{array}$ & 90 days & $\begin{array}{l}\text { To observe } \\
\text { the effect of } \\
\text { yoga on } \\
\text { menopausal } \\
\text { symptoms } \\
\text { using a } \\
\text { prospective, } \\
\text { randomized, } \\
\text { controlled a } \\
\text { nd a } \\
\text { intervention } \\
\text { al study. }\end{array}$ & $\begin{array}{l}\text { It was observed that } \\
\text { on day } 1 \text { the scores in } \\
\text { both the groups were } \\
\text { comparable. On day } \\
90 \text {, the scores in } \\
\text { the yoga } \\
\text { group showed a } \\
\text { reduction in score on } \\
\text { all the subscales, } \\
\text { which } \\
\text { statistically was } \\
\text { significant. No } \\
\text { significant difference } \\
\text { in the control group. }\end{array}$ & $\begin{array}{l}\text { Yoga is effective in } \\
\text { reducing menopausal } \\
\text { symptoms and } \\
\text { should be considered } \\
\text { as alternative therapy } \\
\text { for the management } \\
\text { of menopausal } \\
\text { symptoms. }\end{array}$ \\
\hline $\begin{array}{l}\text { Manoc } \\
\text { ha, } \\
\text { Semma } \\
\text { r, \& } \\
\text { Black } \\
(2007)\end{array}$ & $=14$ & $\begin{array}{l} \pm 55 \text { years } \\
\text { xperience } \\
\text { menopausal } \\
\text { symptoms }\end{array}$ & $\begin{array}{l}\text { Yoga } \rightarrow \\
\text { Meditation } \\
\text { (Sahaja } \\
\text { Yoga) }\end{array}$ & & 8 weeks & $\begin{array}{l}\text { To observe } \\
\text { the impact } \\
\text { of SYM } \\
\text { (Sahaja } \\
\text { Yoga } \\
\text { Meditation) } \\
\text { in } \\
\text { menopausal } \\
\text { symptoms } \\
\text { managemen } \\
\text { t strategy }\end{array}$ & $\begin{array}{l}\text { Yoga changes } \\
\text { In vasomotor } \\
\text { symptoms, especially } \\
\text { hot flashes, were } \\
\text { most prominent as a } \\
\text { significant decrease } \\
\text { of } 67 \% \text { at post- } \\
\text { treatment and } 57 \% \\
\text { and Kupperman's } \\
\text { Index score decreased } \\
\text { by } 58 \% \text { at post- } \\
\text { treatment }\end{array}$ & $\begin{array}{l}\text { These findings } \\
\text { tentatively suggest } \\
\text { that menopausal } \\
\text { symptoms } \\
\text { (vasomotor } \\
\text { symptoms, } \\
\text { and hot } \\
\text { flushes) might be } \\
\text { substantially } \\
\text { improved by } \\
\text { meditation }\end{array}$ \\
\hline $\begin{array}{l}\text { Booth- } \\
\text { LaForc } \\
\text { e, } \\
\text { Thurst } \\
\text { on, \& } \\
\text { Taylor } \\
\text { (2007) }\end{array}$ & $=12$ & $\begin{array}{l}\text { Perimenopau } \\
\text { sal and } \\
\text { postmenopau } \\
\text { sal women }\end{array}$ & $\begin{array}{l}\text { Yoga } \rightarrow \\
\text { Breathing } \\
\text { technique, } \\
\text { warm-up } \\
\text { pose, main } \\
\text { pose, } \\
\text { relaxation } \\
\text { pose }\end{array}$ & & 0 weeks & $\begin{array}{l}\text { To observe } \\
\text { the } \\
\text { effectivenes } \\
\text { s of yoga in } \\
\text { improving } \\
\text { menopausal } \\
\text { symptoms } \\
\text { (Physiology } \\
\text { symptoms } \\
\text { and self- } \\
\text { measuring } \\
\text { of hot } \\
\text { flashes } \\
\text { symptoms) }\end{array}$ & $\begin{array}{l}\text { Eleven women } \\
\text { completed the study } \\
\text { and attended a mean } \\
\text { of } 7.45 \text { (S.D. 1.63) } \\
\text { classes. Significant } \\
\text { pre- to post-treatment } \\
\text { improve } \\
\text { ments were found for } \\
\text { severity of } \\
\text { questionnaire-rated } \\
\text { total menopausal } \\
\text { symptoms, hot-flash } \\
\text { daily interference; } \\
\text { and sleep efficiency } \\
\text { disturbances, and } \\
\text { quality. Neither 24-h } \\
\text { monitoring nor } \\
\text { accompanying diaries } \\
\text { yielded significant } \\
\text { changes in hot flashes }\end{array}$ & $\begin{array}{l}\text { Yoga is suitable to } \\
\text { be implemented to } \\
\text { midlife woman. } \\
\text { Yoga may have a } \\
\text { broad impact on } \\
\text { coping with } \\
\text { menopausal changes } \\
\text { rather than } \\
\text { specifically hot } \\
\text { flushes }\end{array}$ \\
\hline $\begin{array}{l}\text { Tuzun, } \\
\text { Aktas, } \\
\text { Akarir } \\
\text { mak, } \\
\text { Sipahi, } \\
\& \\
\text { Tuzun } \\
(2010)\end{array}$ & $\begin{array}{l}=26 \\
2 \text { group } \\
\text { oga (13), } \\
\text { ontrol } \\
(13)\end{array}$ & $\begin{array}{l} \pm 55 \text { tahun } \\
\text { Postmenopau } \\
\text { sal with } \\
\text { osteoporotic }\end{array}$ & $\begin{array}{l}\text { Yoga } \rightarrow 2 \\
\text { times in } \\
\text { one week } \\
\text { @ } 1 \text { hour }\end{array}$ & $\begin{array}{l}\text { Control } \rightarrow \\
\text { classic } \\
\text { osteoporotic } \\
\text { exercises } \\
\text { (strengtheni } \\
\text { ng and } \\
\text { stretching } \\
\text { exercise of } \\
\text { the } \\
\text { abdominal, } \\
\text { back, } \\
\text { quadriceps, }\end{array}$ & 2 weeks & $\begin{array}{l}\text { To evaluate } \\
\text { the effect of } \\
\text { yoga } \\
\text { exercises in } \\
\text { postmenopa } \\
\text { usal } \\
\text { osteoporotic } \\
\text { women on } \\
\text { balance and } \\
\text { life quality } \\
\text { and to } \\
\text { compare the }\end{array}$ & $\begin{array}{l}\text { The result showed } \\
\text { that yoga education } \\
\text { has a positive effect } \\
\text { on pain, physical } \\
\text { functions, social } \\
\text { function, general } \\
\text { health perception and } \\
\text { balance. }\end{array}$ & $\begin{array}{l}\text { Yoga appears to be } \\
\text { an alternative } \\
\text { physical activity for } \\
\text { the rehabilitation of } \\
\text { osteoporotic } \\
\text { subjects. }\end{array}$ \\
\hline
\end{tabular}




\begin{tabular}{|l|l|l|l|l|l|}
\hline & & & $\begin{array}{l}\text { and } \\
\text { hamstring } \\
\text { muscles, } \\
\text { balance and } \\
\text { posture } \\
\text { exercise (2 } \\
\text { time in one } \\
\text { week @ 1 } \\
\text { hour) }\end{array}$ & $\begin{array}{l}\text { results with } \\
\text { a classic } \\
\text { osteoporosis } \\
\text { exercise } \\
\text { program. }\end{array}$ \\
\end{tabular}

.Based on the summary of journal characteristic above, a study will be done to acquire recommendation about several possible research that can be done in Indonesia. The study is categorized into several subtheme which are research subject, purpose of research and result of research.

\section{Research Subject, Purpose of Research, and Result of Research}

From 10 reviewed research, there are 8 research which subjects is postmenopause and 2 research using perimenopause as the subject. All of the research are involving subject with regular menopause cycle which happened according to the age limit of the corresponding woman, which is around 40-65 years of age and experiencing any menopausal symptoms. Some researcher are also states that subject was not in a therapy or any other treatment such as hormone therapy or any yoga therapy before.

The implemented treatment is Yoga with several techniques, which are breathing technique, posture, relaxation and meditation which are practiced and supervised by the Yoga expert. Measurement is done between 8 and 16 weeks with duration about 30-60 minutes. The purpose of the Yoga exercise in these 10 research is to decrease any showed symptoms during and after menopause which are psychological, vasomotor and somatic symptoms. Most of the research shows that there are connections between Yoga and hot flashes (vasomotor symptoms) because those symptoms will be mostly experienced by woman right before menopause. Routine Yoga exercise is shown to be effective in reducing the frequency of hot flashes. At most of the research are also included control group which receives no treatment. By comparing control group and Yoga group, it is evident that yoga are more effective in reducing menopausal symptoms.

Next researcher also states that yoga effectively reducing the severity of insomnia experienced by woman with menopausal symptoms because in yoga there are relaxation techniques which reduce the uneasiness during menopause. Not only improving insomnia condition, yoga also reduces anxiety, stress, depression and neuroticism by practicing relaxation and meditation techniques in yoga. Yoga also serves as one of the alternative therapy in helping woman in menopause in dealing with osteoporosis by reducing the pain, improving physical function, social function, general health perception and body balance. Research done by Afonso, Kozasa, Rodrigues, Leitem Tufgik \& Hachul (2016) founds that yoga also affects neuroendocrine system which increases the amount of estrogen hormone which also increases the quality of life.

\section{CONCLUSION}

Yoga could serve as an alternative in reducing symptoms which caused by menopause cycle, such as psychological, vasomotor and somatic symptoms. Yoga exercise, if done and supervised properly in a systematic manner will have a positive impact for woman with menopause

\section{REFERENCES}

Afonso, R. F., Hachul, H., Kozasa, E. H., Oliveira, D. S., Goto, V., Rodrigues, D., Tufik, S., \& Leite, J. R., (2012). Yoga decrease insomnia in postmenopausal women: a randomized clinical trial. Menopause: The Journal of The North American Menopause Society, 19(2), 186-193.

Afonso, R. F., Kozasa, E. H., Rodrigues, D., Leite, J. R., Tufik, S., \& Hachul, H., (2016). Yoga increased serum estrogen levels in postmenopausal women-a case report. Menopause: The Journal of The North American Menopause Society. 23(5), 584-586.

Booth-LaForce, C., Thurston R. C., \& Taylor M. R., (2007). A pilot study of a hatha yoga treatment for menopausal symptoms. Maturitas. 57(3), 286-295.

Chattha, R., Raghuram, N., Venkatram, P., Hongasandra, N. R., (2008). Treating the climacteric symptoms in Indian women with an integrated approach to yoga therapy: a randomized control study. Menopause: The Journal of The North American Menopause Society. 15(5), 862-870.

Cohen, BE., Kanaya, AM., Macer, JL., Shen, H., Chang, A., \& Grady, D. (2007). Feasibility and acceptability of restorative yoga for treatment of hot flushes:A pilot trial. Maturitas The European Menopause Journal. 56, 198-204.

Cohen, L., \& Wameke, C., (2004). Psychological adjustment and sleep quality: A randomized trial of the effects of a Tibetan yoga intervention in patients with lymphoma. Cancer. (100), 2253-2260.

Cooper, H., Mishra, G., Clennell, S., Guralnik, J., \& Kuh, D. (2008). Menopausal status and physical performance in midlife: findings from a British birth cohort study. Menopause Journal, 15 (6), 10791085 .

Cramer, H., Lauche, R., Langhorst, J., \& Dobos, G., (2012). Effectiveness of yoga for menopausal symptoms: A systematic review and meta-analysis of randomized controlled trials. Evidence-Based Complementary and Alternative Medicine.

Innes, K., Bourguignon, C., \& Taylor, A. (2005). Risk indices associated with insulin resistance syndrome, cardiovascular disease, and possible protection with yoga: A systematic review. J Am Board Fam Pract. 18. 491-519.

Joshi, S., Khandwe, R., Bapat, D., \& Deshmukh, U., (2011). Effect of yoga on menopausal symptoms. Menopause International. 17(3), 78-81.

Khalsa, SB., (2004). Treatment of chronic insomnia with yoga: A preliminary study with sleep wake diaries. Appl Psycho Physiol Biofeed Back, 29, 269-278. 
Lee, J., Kim, J., \& Kim, D., (2012). Effects of yoga exercise on serum adiponectin and metabolic syndrome factors in obese postmenopausal women. Menopause: The Journal of The North American Menopause Society, 19 (3), 296-301.

Manocha, R., Semmar, B., \& Black, D., (2007). A pilot study of a mental silence form of meditation for women in perimenopause. Journal of Clinical Psychology in Medical Settings, 14 (3), 266-273.

McVeigh, C. (2005). Perimenopause: More than hot flushes and night sweats for some Australian women. $J$ Obstet Gynecol Neonatal Nurs, 34 (1), 21-27.

Newton, K. M., Reed, S. D., Guthrie, K. A., Sherman, K. J., LaForce, C. B., Caan, B., Sternfeld, B., Carpenter, J. S., Learman, L. A., Freeman, E.W., Cohen, L. S., Joffe, H., Anderson, G. L., Larson, J. C., Hunt, J. R., Ensrud, K. E., \& LaCroix, A. Z., (2013). Efficacy of yoga for vasomotor symptoms: a roandomized controlled trial. Menopause: The Journal of The North American Menopause Society, 21 (4), 339346.

Nichols, H. B., Trentham-Dietz, A., Newcomb, P. A., Titus, L. J., Egan, K. M., Hampton, J. M., \& Visvanathan, K. (2012). Postoophorectomy estrogen use and breast cancer risk. Obstetrics and Gynecology, 120(1), 2736.

Santrock, John W. (2012). Life-Span Development: Perkembangan Masa Hidup (Edisi ketigabelas). (Penerj. Benedictine Widyasinta; Ed. Novietha Sallama). Jakarta : Erlangga.

Torre, P., Leon, D., Mora, F., Salinas, A., Robinson, R., \& Refaat, A. (2015). Nutrition and women's health. Global Health Through Education Learning and Service, 1(2), 1-10.

Tuzun, S., Aktas, I., Akarirmak, U., Sipahi, S., \& Tuzun, F. (2010). Yoga might be an alternative training for the quality of life and balance in postmenopausal osteoporosis. European Journal of Physical and Rehabilitation Medicine, 46 (1), 69-72 